\title{
HUBUNGAN IKLIM KELAS DENGAN HASIL BELAJAR SISWA KELAS XI SMAN 8 BATAM
}

\section{THE RELATIONSHIP BETWEEN CLASS CLIMATE AND STUDENTS' LEARNING OUTCOMES AT CLASS XI SMAN 8 BATAM}

\author{
Wening Kadarsih ${ }^{1}$, Ramses $^{2 *}$, Yarsi Efendi ${ }^{3}$ \\ ${ }^{123}$ Program Studi Pendidikan Biologi, FKIP, UNRIKA, Batam \\ *Korespondensi : ramses.firdaus@gmail.com
}

\begin{abstract}
Abstrak
Penelitian bertujuan untuk mengetahui hubungan iklim kelas dengan hasil belajar siswa pada materi sistem reproduksi di kelas XI IPA SMAN 8 Batam Tahun Pelajaran 2013/2014. Jenis penelitian dengan desain korelasi sederhana dimana populasi terjangkau yaitu seluruh kelas XI IPA, kemudian pengambilan sampel secara acak sederhana (simple random sampling) dengan cara undian dan terpilih kelas $\mathrm{XI}_{1}, \mathrm{XI}_{3}$ dan $\mathrm{XI}_{4}$. Instrumen penelitian menggunakan angket iklim kelas (Y) serta hasil belajar siswa (X) yang diperoleh dari guru mata pelajaran yang kemudian dianalisis uji hipotesis dengan korelasi product moment dari Pearson. Hasil pengujian diperoleh nilai koefisien determinasi $\left(\mathrm{R}^{2}\right)$ sebesar $0,349(34.9 \%)$ artinya bahwa faktor iklim belajar kelas hanya memberikan konstribusi pengaruh sebesar 34,9\% sisanya dipengaruhi oleh faktor lainnya. Sedangkan nilai koefisien korelasi (r) sebesar $0.591(59,1 \%)$ memberikan gambaran bahwa ada hubungan yang cukup baik dan nyata antara iklim belajar kelas dengan hasil belajar siswa kelas XI materi sistem reproduksi.
\end{abstract}

Kata Kunci : Hubungan, Iklim kelas, Hasil belajar

\begin{abstract}
The study aims to determine the relationship between class climate and student learning outcomes on reproductive system material in class XI IPA SMAN 8 Batam academic year 2013/2014. The type of research was simple correlation design where whole class XI IPA students became as population, then simple random sampling by lottering, class $X I_{._{1}}, X_{I_{2},}, X_{._{3}}$ and $X_{._{4}}$ were selected. The research instrumentwas used classroom climate questionnaire $(Y)$ and student learning outcomes $(X)$ obtained from teachers, then they were analyzed by using hypothesis test of Pearson product moment correlation. The test results obtained that coefficient of determination $\left(R^{2}\right)$ of $0.349(34.9 \%)$, it means that the learning climate factors only contributed influence on ammount $34.9 \%$, remaining was influenced by other factors. While the correlation coefficient ( $r$ ) value was 0591 (59.1\%) which suggests that there was a good and real relationship between learning climate and students learning outcomes on reproductive systemsubject.
\end{abstract}

Keywords: Relationships, classroom climate, learning outcomes

\section{PENDAHULUAN}

Proses pembelajaran seharusnya mampu menciptakan suasana kelas atau iklim kelas yang kondusif untuk mendukung terciptanya kualitas proses pembelajaran. Namun sayangnya proses pembelajaran yang terjadi selama ini masih cenderung satu arah, kurang memperhatikan partisipasi aktif siswa dalam proses pembelajaran. Guru cenderung belum menempatkan dirinya sebagai fasilitator, motivator, dan dinamisator dalam suatu proses 
pembelajaran yang lebih menempatkan peserta didik sebagai subjek belajar. Guru lebih cenderung menempatkan dirinya sebagai satu-satunya sumber belajar, sehingga peserta didik selama ini lebih cenderung dianggap sebagai objek belajar yang harus menerima segala sesuatu yang akan diberikan oleh guru. Akibatnya proses pembelajaran yang terjadi selama ini kurang bermakna bagi siswa, sehingga belum mampu mengembangkan kompetensi dan potensi kemampuan siswa secara lebih optimal.

Di banyak tempat, penelitian tentang iklim kelas belum begitu dikembangkan, umumnya guru dan kepala sekolah belum terlalu memahami. Padahal iklim kelas diyakini berkorelasi dengan prestasi hasil belajar siswa. Oleh karena itu memulai studi tentang iklim kelas dengan tujuan peningkatan kualitas pembelajaran disekolah menjadi sangat penting dan dibutuhkan (Hadianto \& Subijanto, 2003 dalam Tarmidi dan Wulandari, 2005). Terlebih pada anak berbakat yang memerlukan pelayanan khusus dalam pendidikannya. Menurut pendapat Moos yang di kutip dari Baek dan Choi (2002) dalam Tarmidi dan Wulandari (2005), persepsi siswa mengenai lingkungan belajar termasuk ruang kelas, dimana siswa menghabiskan sebagian besar waktunya, memberikan arti penting yang dapat mempengaruhi aktifitas belajar. Siswa akan antusias dalam menerima pembelajaran apabila pelajaran yang diberikan oleh guru memuaskan ,menantang, dan ramah serta membuat mereka mempunyai hak untuk bersuara dalam pengambilan keputusan. Sedangkan menurut Walberg yang dikutip dari Fathaigh (1997) dalam Tarmidi dan Wulandari (2005) menyatakan bahwa kejadian-kejadian dan kondisi dalam lingkungan sosial dan persepsi pelajar terhadap iklim belajar sangat signifikan dalam memprediksi prestasi. Hal tersebut senada dengan pernyataan Fraser yang dikutip dari Yates (2001) dalam Tarmidi dan Wulandari (2005) yang menyatakan bahwa iklim kelas dapat mempengaruhi pembelajaran siswa.

Iklim kelas merupakan salah satu faktor penunjang dalam kegiatan pembelajaran. Dalam hal ini guru berperan sangat penting dalam mengatur kegiatan didalam lingkungan kelas. Apabila didalam kelas kondisinya kurang baik maka siswa akan sangat terganggu dalm kegiatan belajarnya. Guru harus bisa menempatkan siswanya mana yang harus berada dibarisan depan maupun yang ada dibelakang. Dengan suasana kelas yang kondusif maka siswa akan mudah untuk bisa lebih fokus dalam menerima materi yang diajarkan.

Dilihat dari peranan guru sebagai seorang pendidik, pembimbing, pelatih dan pemimpin yang dapat menciptakan iklim kelas yang menarik, aman, nyaman, 
keberadaannya di tengah-tengah siswa dapat mencairkan suasana, kekakuan, dan kejenuhan belajar yang terasa berat diterima oleh para siswa. Iklim kelas yang tidak kondusif akan berdampak negatif terhadap proses pembelajaran dan sulitnya tercapai tujuan pembelajaran, siswa akan merasa gelisah, resah, bosan, dan jenuh. Sebaliknya dengan iklim kelas yang yang kondusif dan menarik dapat dengan mudah mencapai tujuan pembelajaran,dan proses pembelajaran yang dilakukan menyenangkan bagi peserta didik (Husna, 2013).

Dari hasil observasi yang dilakukan menunjukkan iklim kelas yang kondusif untuk mengembangkan kreatifitas, kecakapan, kemandirian serta kerjasama antara guru dengan siswa atau antara sesama siswa belum dapat tercipta dengan baik. Selain itu masih kurangnya peran seorang guru dalam menanggapi perilaku siswa baik yang berperilaku positif maupun yang berperilaku negatif sehingga siswa berperilaku semaunya sendiri, tanpa memperhatikan aturan-aturan yang telah ditetapkan disekolah. Faktor lain yang tidak kalah pentingnya yaitu pada siswa kelas XI di SMA Negeri 8 Batam memiliki jumlah siswa yang cukup banyak,yaitu dari total 6 kelas sebanyak 214 siswa, yang masing-masing kelas berjumlah 33-38 siswa, menambah suasana di dalam kelas semakin kurang efektif.

Guru harus bekerja keras dalam menciptakan situasi lingkungan yang nyaman dan kondusif agar siswa dalam menerima materi pembelajaran lebih mudah untuk dipahami. Untuk itu peneliti akan mencoba melakukan penelitian untuk dapat membuktikan ada atau tidaknya hubungan iklim kelas dengan hasil belajar siswa kelas XI materi sistem reproduksi di SMA Negeri 8 Batam.

\section{METODOLOGI}

Penelitian ini merupakan penelitian dengan pendekatan kuantitatif yang menggunakan metode korelasional dengan desain penelitian korelasi sederhana. Variabel bebas penelitian ini adalah hasil belajar dan variabel terikatnya adalah iklim kelas. Penelitian ini dilaksanakan di SMA Negeri 8 Batam dari bulan juni-juli tahun 2014. Populasi penelitian adalah siswa Kelas XI IPA SMA Negeri 8 Batam dengan jumlah 214 orang. Dengan menggunakan teknik Simple Random Sampling, didapatkan jumlah sampel sebanyak 106 orang.

Instrumen penelitian berupa angket iklim kelas dengan 4 sub variabel, yaitu Kekompakan siswa dalam kelas. Keterlibatan siswa dalam pembelajaran IPA Biologi. 
Kepuasan siswa mengikuti pembelajaran IPA Biologi. Dukungan guru dalam pembelajaran IPA Biologi. validasi instrumen dilakukan melalui uji coba kepada siswasiswi SMA N 8 Batam dengan jumlah subjek uji coba sebanyak 30 orang siswa. Berdasarkan hasil uji coba disimpulkan bahwa kuesioner karakteristik siswa peduli lingkungan diperoleh 24 butir pernyataan yang valid. Analisis data dilakukan menggunakan analisis statistik deskriptif dan analisis korelasi sederhana Product Moment dengan bantuan program SPSS 20.

\section{PEMBAHASAN}

Data karakteristik siswa peduli lingkungan seluruh siswa kelas XI IPA SMA N 8 Batam yang menjadi sampel penelitian meliputi : jumlah sampel sebanyak 106 orang dengan total skor sebesar 8528, skor maksimum 94 dan skor minimum 65. Dari analisis statistik deskriptif diperoleh data rerata sebesar 80.45, modus 83 dan median 82, standar deviasi sebesar 6.38, dan varian 40.76, Distribusi frekuensi data meliputi rentang sebesar 31, banyak kelas interval (k) sebanyak 8 kelas dan panjang kelas interval sebesar 4 .

Tabel 1. Rekapitulasi Deskriptif Data Iklim Kelas

\begin{tabular}{cll}
\hline No & Statistik Deskriptif & Nilai Iklim Kelas \\
\hline 1 & Jumlah Sampel (n) & 106 \\
2 & Jumlah Total Data & 8528 \\
3 & Data Maksimum & 94 \\
4 & Data Minimum & 65 \\
5 & Rentang & 29 \\
6 & Rerata & 80.45 \\
7 & Modus & 83 \\
8 & Median & 82 \\
9 & Simpangan Baku & 6.38 \\
10 & Varian & 40.76 \\
\hline
\end{tabular}

Data hasil belajar seluruh siswa kelas XI IPA SMA N 8 Batam yang menjadi sampel penelitian meliputi : jumlah sampel sebanyak 106 orang dengan total skor sebesar 7812, skor maksimum 90 dan skor minimum 50. Dari analisis statistik deskriptif diperoleh data rerata sebesar 40, modus 73.69 dan median 85, standar deviasi sebesar 10.40, dan varians 108.2. 
Tabel 2. Rekapitulasi Deskriptif Data Hasil Belajar

\begin{tabular}{cll}
\hline No & Statistik Deskriptif & Nilai Iklim Kelas \\
\hline 1 & Jumlah Sampel (n) & 106 \\
2 & Jumlah Total Data & 7812 \\
3 & Data Maksimum & 90 \\
4 & Data Minimum & 50 \\
5 & Rentang & 40 \\
6 & Rerata & 73.69 \\
7 & Modus & 85 \\
8 & Median & 75 \\
9 & Simpangan Baku & 10.40 \\
10 & Varian & 108.2 \\
\hline
\end{tabular}

Hasil perhitungan normalitas kelompok data nilai iklim kelas (X) menggunakan uji Kolmogorov Smirnov dengan program SPSS 20 diperoleh nilai Asymp.Sig. sebesar 0.066. Dari hasil perhitungan terlihat bahwa nilai Asymp.Sig. (0.721) > $\alpha(0.05)$ yang berarti data berdistribusi normal. Sedangkan hasil perhitungan normalitas data nilai hasil belajar siswa (Y) diperoleh nilai Asymp.Sig sebesar 0.071. Dari hasil perhitungan terlihat bahwa nilai Asymp.Sig (0.680) > $\alpha(0.05)$ yang berarti data berdistribusi normal. Rekapitulasi hasil uji normalitas disajikan dalam Tabel 3.

Tabel. 3 Rekapitulasi Hasil Uji Normalitas (One Sample Kolmogrovo-Smirnov Test)

\begin{tabular}{llcc}
\hline & & Iklim Kelas & Hasil Belajar \\
\hline $\mathrm{N}$ & & 106 & 106 \\
Normal Parameters & Mean & 80.4528 & 73.6981 \\
& Std. Deviation & 6.38470 & 10.40345 \\
Most Extreme & Absolute & 127 & 125 \\
Differences & Positive & 062 & 099 \\
& Negative & -127 & -125 \\
Kolmogorov-Smirnov Z & 1.3 & 1.292 \\
Asymp. Sig. (2-tailed) & 066 & 071 \\
\hline
\end{tabular}

Tabel 4. Rekapitulasi Hasil Uji Homogenitas Hasil Belajar

\begin{tabular}{cccc}
\hline Levene Statistic & df1 & df2 & Sig. \\
1.515 & 21 & 79 & .096 \\
\hline
\end{tabular}

Dari Tabel 4 di atas dapat dilihat bahwa diperoleh nilai Sig. sebesar 0.096. Nilai Sig.0.096 > $\alpha$ (0.05), maka dapat disimpulkan bahwa data berasal dari varian yang sama (homogen). Hasil pengujian menunjukkan bahwa prasyarat normalitas data untuk 
pengujian hipotesis terpenuhi, maka dengan demikian analisis dapat dilanjutkan untuk menguji hipotesis penelitian yang diajukan.

Berdasarkan Tabel 5 Correlations di atas diperoleh koefisien korelasi (r) sebesar 0.591. Koefisien korelasi (r) sebesar 0.591 menunjukkan bahwa hubungan antara iklim kelas dengan hasil belajar siswa adalah berada dikriteria tinggi dan bersifat positif. Hasil perhitungan pada Tabel 5 Correlations di atas didapatkan Sig sebesar 0.000. Sig=0.000 < $\alpha(0.05)$, maka Ho ditolak. Keputusannya yaitu terdapat hubungan yang signifikan antara iklim kelas (X) dengan hasil belajar siswa (Y). Hasil pengujian ini menunjukkan bahwa hipotesis penelitian yang diajukan yaitu terdapat hubungan yang signifikan antara iklim kelas (X) dengan hasil belajar siswa (Y) diterima.

Tabel 5. Rekapitulasi Korelasi Hasil Belajar dengan Iklim Belajar

\begin{tabular}{clcc}
\hline PARAMETER & \multicolumn{1}{c}{ KORELASI } & IKLIM KELAS & HASIL BELAJAR \\
\hline \multirow{3}{*}{ Iklim Kelas } & Pearson Correlation & 1 & $.591^{* *}$ \\
& Significan (2-tailed) & - & .000 \\
& $\mathrm{~N}$ & 106 & 106 \\
& Pearson Correlation & $.591^{* *}$ & 1 \\
\multirow{3}{*}{ Iklim Belajar } & Significan (2-tailed) & .000 & - \\
& $\mathrm{N}$ & 106 & 106 \\
\hline
\end{tabular}

** Correlation is significant at the 0.01 level (2-tailed)

Penciptaan iklim kelas yang kondusif sangat mendukung untuk terlaksananya proses belajar mengajar yang baik, sehingga akan memunculkan sikap belajar yang baik pula pada diri siswa. Keras atau tidaknya usaha belajar peserta didik bergantung pada besar tidaknya penciptaan iklim kelas yang kondusif. Untuk itu, penciptaan iklim kelas harus kondusif karena siswa akan menjadi sadar bahwa ia harus dapat mencapai tujuan belajarnya, yaitu untuk mendapatkan hasil belajar yang maksimal .

Jika sekolah tidak bisa menunjang kebutuhan fasilitas tersebut, maka hal tersebut akan menjadi faktor penghambat dalam kegiatan belajar. Hasil penelitian yang peneliti lakukan menunjukkan penciptaan iklim kelas telah memberikan pengaruh yang positif untuk hasil belajar siswa. Hal ini dikarenakan sekolah telah mampu memenuhi segala fasilitas kelas dengan sempurna serta sarana dan prasarana, seperti: perpustakaan, laboratorium IPA, laboratorium bahasa, aula sekolah, dan masjid. Oleh karena itu, sekolah 
telah memberikan fasilitas belajar yang memadai, sehingga dapat membangkitkan semangat serta menumbuhkan aktivitas dan kreativitas siswa.

Hasil penelitian tersebut juga sesuai dengan penelitian yang dilakukan oleh Husna, Buwono, dan Matsum (2013) dengan judul penelitian "pengaruh iklim kelas dan minat belajar terhadap hasil belajar siswa". Hasil penelitiannya menunjukkan bahwa terdapat pengaruh positif antara iklim kelas terhadap hasil belajar sebesar 15.3\%. Selanjutnya penelitian yang dilakukan oleh Tarmidi (2006) dengan judul penelitiannya "iklim kelas dan prestasi belajar" hasil penelitiannya menunjukkan bahwa iklim kelas berkorelasi positif dengan prestasi belajar siswa. Parsons \& Hinson (2001) dalam Puspitasari (2012) menyatakan bahwa salah satu faktor yang dapat mendorong atau menghalangi motivasi belajar siswa adalah iklim kelas. Iklim kelas yang dirasakan aman oleh siswa akan mendukung siswa dalam belajar. Namun iklim yang terbentuk dalam kelas juga dapat dirasakan mengancam oleh siswa dan berakibat pada rendahnya keterlibatan siswa dalam belajar. Tokoh lain seperti Kauchak \& Eggen (2004) dalam Puspitasari (2012) juga menyatakan bahwa iklim kelas memiliki peran penting dalam menciptakan suatu lingkungan yang dapat meningkatkan motivasi belajar dan prestasi siswa. Iklim kelas yang mendukung siswa dalam belajar akan membuat siswa merasa aman, bebas dalam menyampaikan ide-ide yang dimiliki, serta mempunyai kualitas yang baik dalam kelas, seperti saling memberikan perhatian dan saling menghargai sehingga akan membuat siswa lebih terdorong untuk belajar.

Berdasarkan uraian di atas maka terdapat hubungan yang signifikan antara iklim kelas dengan hasil belajar siswa kelas X pada materi sistem reproduksi di SMA Negeri 8 Batam. Hal tersebut terbukti secara analisis statistik inferensial dan beberapa penelitian relevan serta berdasarkan pendapat para ahli.

\section{KESIMPULAN}

Berdasarkan hasil dan pembahasan analisis deskriptif dan pengujian hipotesis, dapat ditarik kesimpulan sebagai berikut : Pengujian korelasi Product Moment menunjukkan korelasi (r) sebesar 0.591. Selanjutnya uji signifikansi korelasi, diperoleh nilai Sig. $=0.000$, pada $\alpha(0.05)$, terlihat bahwa nilai Sig $<0.05$ yang berarti menolak Ho, 
kesimpulan menolak Ho menunjukkan bahwa terdapat hubungan yang signifikan antara karakteristik siswa peduli lingkungan dengan haswil belajar siswa.

Berdasarkan dari latar belakang penelitian dan teori yang digunakan untuk mengetahui apakah terdapat hubungan antara iklim kelas dengan hasil belajar siswa serta melalui pengujian statistik inferensial dibuktikan bahwa terdapat hubungan yang signifikan antara iklim kelas dengan hasil belajar biologi pada siswa kelas X di SMA Negeri 8.

\section{REFERENSI}

Arikunto, S. 2010. Prosedur Penelitian Suatu Pendekatan Praktik. PT. Rineka Cipta. Jakarta.

Aunurrahman, 2011. Belajar dan Pembelajaran, Alfabeta. Bandung.

Dimyati dan Mudjiono, 2013. Belajar Dan Pembelajaran. PT.Rineka Cipta. Jakarta.

Hadinata, 2009. Iklim Kelas dan Motivasi Belajar Siswa SMA. Jurnal Psikologi. Vol.3 No.1.

Iskandar, 2012. Psikologi Pendidikan. Referensi. Jakarta.

Jufri, A.W. 2013. Belajar dan Pembelajaran SAINS. Reka Cipta. Bandung.

Mulyatiningsih, E. 2012. Metode Penelitian Terapan Bidang Pendidikan. Alfabeta. Bandung.

Riduwan, 2011. Dasar-dasar Statistika. Bandung : Alfabeta.

Rusman, 2012. Belajar Dan Pembelajaran Berbasis Komputer. Alfabeta. Bandung.

Sugiyono, 2011. Statistik Untuk Penelitian. Alfabeta. Bandung .

Sugiyono, 2012. Metode Penelitian Pendidikan. Alfabeta. Bandung.

Sutikno, S. 2013. Belajar Dan Pembelajaran. Holistica. Lombok .

Tarmidi dan Wulandari. 2005. Prestasi Belajar di Tinjau dari Persepsi Siswa Terhadap Iklim Kelas pada Siswa yang Mengikuti Program Percepatan Belajar. Jurnal Psikologia. Vol. 1 No. 1. 